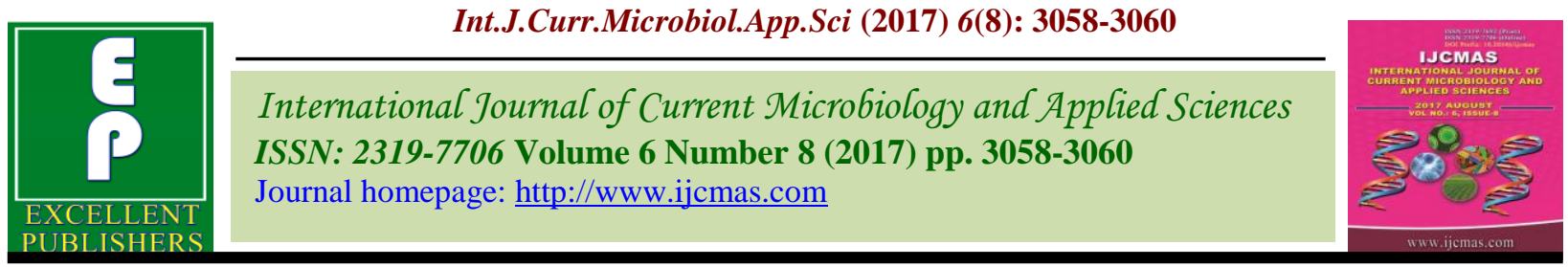

Original Research Article

https://doi.org/10.20546/ijcmas.2017.608.365

\title{
Occurrence of Black Spot of Rose, Marssonina rosae from Himachal Pradesh, India
}

\author{
Sunita Chandel*, Praneet Chauhan and Reetika Panwar \\ Department of Plant Pathology, Dr. Y.S. Parmar University of Horticulture and Forestry, \\ Nauni, Solan 173230, H.P., India \\ *Corresponding author
}

\section{A B S T R A C T}

Keywords

Conidia,

pathogenicity,

Marssonina rosae

Article Info

Accepted:

23 June 2017

Available Online:

10 August 2017
Black spot disease is serious threat to rose production in India. Black spot of rose caused by Marssonina rosae (Lib.) Lind. with its perfect stage Diplocarpon rosae (Wolf) causes heavy losses to roses worldwide. Therefore preliminary investigations were undertaken with the objective to record the outbreak of black spot of rose in Solan and Sirmour districts of Himachal Pradesh, India. The pathogen was identified based on the morphological features as Marssonina rosae (Lib.) Lind. Most distinguishing morphological features of pathogen were production of cylindrical, two celled and hyaline conidia measuring in length $(22.1-25.3$ $\mu \mathrm{m})$ and width $(5.3-7.1 \mu \mathrm{m})$. The pathogenicity was obtained within 15days of inoculation.

\section{Introduction}

Rose black spot, caused by Diplocarpon rosae F.A. Wolf (imperfect stage Marssonina rosae (Lib.) Lind.) is the most important disease of the rose worldwide (Baker, 1948; Baskaran and Ranganathan, 1974) except in regions of low seasonal rainfall. In India rose is preferred over other flowers as the most popular flowering plants and is on top ranking as cut flower in the flower trade on the basis of acreage, production and consumption. The total area under flowers is estimated to be 243 thousand ha with annual production of 2236 thousand MT (Anonymous, 2014 - 2015). However in Himachal Pradesh total area covered under flowers is 0.79 thousand ha with 27.21 thousand MT of loose and 12.06 thousand
MT of cut flower production in year 2015 while 0.04 thousand ha area is under cultivation of rose and as a cut flower the production of rose is 1.98 thousand MT in 2014 and about 30,000 no. cut flowers produced in 2015 according to the database of NHB and Directorate of Horticulture, HP (Anonymous, 2015-2016). Though, black spot is a minor problem in greenhouse roses because humidity is regulated very carefully but is the most important disease of outdoor roses. The rose plant is used in gardens and landscaping for its aesthetic value, but the black spot infections make the roses unsightly due to the black spots on the leaves, yellowing and premature defoliation. However in the past few years, its production 
declines probably due to a severe outbreak of leaf spot in roses mainly in July-August with the onset of rainy season, which has occurred consistently in almost all the rose growing provenances of Himachal Pradesh, India.

\section{Symptoms}

Initially lesions develop as small dark areas which vary in size from $2-12 \mathrm{~mm}$, later enlarge with circular or irregular shapes and become dark brown to black in color with fringed margins. In severe infections, on coalescing bigger spots form accompanied by yellowing around the lesions on infected leaves and later resulted into severe defoliation. Acervuli of the fungus can be readily seen on foliar lesions as small black pustular structures (Debener and Byrne, 2014). Similar symptoms had also been reported by various workers (Horst, 1983; Mangadi and Peres, 2009).

\section{Pathogen}

The pathogen was isolated from tissues of the periphery of the infected rose leaves collected from the two rose growing provenances, Solan and Sirmour on potato dextrose agar medium (PDA). The samples were sterilised first in $0.01 \%$ mercuric chloride solution for 30 seconds and washed with sterile distilled water three times before transferring to PDA. After incubation at $25^{\circ} \mathrm{C}$ for $12-14$ days, hyphal tips were transferred to fresh PDA and the resulting pure culture was accomplished, colonies were used for microscopic examination. Off white colonies usually formed and depending on cultivars, these later became pinkish cinnamon color or light mouse grey, clove brown with apricot and salmon buff mixtures (Figs. 1 and 2). Hyphae were prostrate, hyaline, variously branched, often sepate. The pathogen was characterized with cylindrical, straight to slightly curved, obvoid, usually crescent-shaped, and divided by a cross-wall into two equal cells, hyaline conidia measuring in length $(22.1-25.3 \mu \mathrm{m})$ and width $(5.3-7.1 \mu \mathrm{m})$ (Fig. 3).

The detail of the morphological characters were compared with keys documented by Wenefrida and Spencer (1993) and identified as Marssonina rosae (Lib.) Lind. The pure culture was also identified by National Centre of Fungal Taxonomy, New Delhi, with accession No 7839.16.

Fig.1\&2 Pure culture of Marssonina rosae

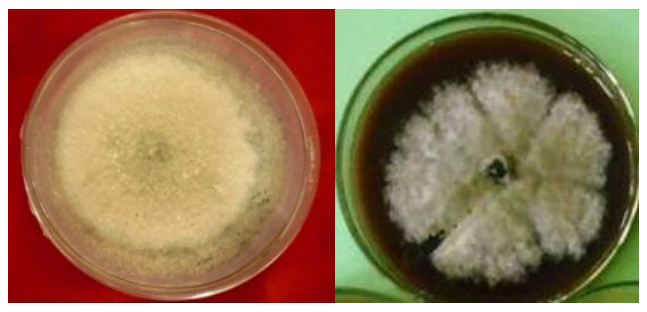

Fig.3 Conidia of Marssonina rosae

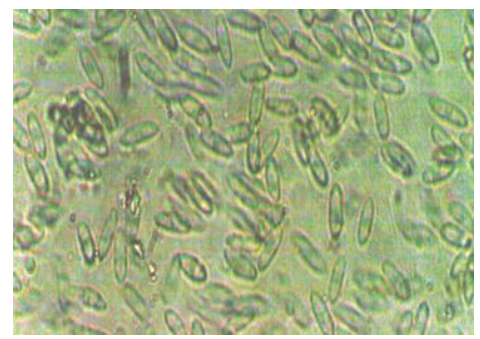

Fig.4 Pathogenicity test of Marssonina rosae

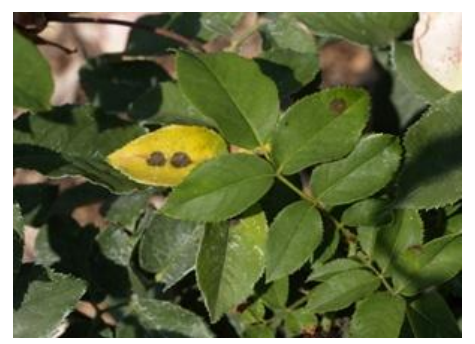




\section{Pathogenecity assay}

Pathogenicity test (Fig. 4) was conducted on highly susceptible variety 'White Delight' under pot culture artificially by spray inoculation method with conidial suspension $\left(8 \times 10^{5}\right.$ conidial $\left./ \mathrm{ml}\right)$. The symptoms appeared after 15 days of inoculation, with initiation after 7 days. The pathogen was reisolated from the infected leaf tissues on PDA medium and microscopic characters were compared that resembled with those of the tested pathogen thus confirming the Koch's postulates. The disease was first reported in Sweden in 1815 and also evident in U.S.A, South America, Canada, Australia, China, Europe and among other countries (Mangandi and Peres, 2009). To the authors' knowledge, this is the first report of Marssonina rosae causing black spot of rose in Himachal Pradesh, India where the outbreak of the pathogen became more intensive and dominant with high relative humidity, wet and cool climate conditions.

\section{Acknowledgements}

The authors would like to extend their thanks to Professor and Head of the Department of Plant Pathology, Dr. YSP University of Horticulture and Forestry, Nauni, Solan (H.P)-India for providing the financial assistance to conduct the present study.

\section{References}

Anonymous. 2014-2015 http://www.nhb. gov. in.

Anonymous. 2015-2016. Directorate of Horticulture, Shimla HP.

Baker, K. F., 1948. The history, distribution and nomenclature of the rose black spot fungus. Plant Dis. Report., 32: 260274.

Baskaran, D. E., and Ranganathan, K. 1974. Physiological changes in rose leaves, infected by Diplocarpon rosae. Phytopathol, 79: 231-236.

Debener, T., and Byrne D. H. 2014. Disease resistant breeding in rose: current status and potential of biotechnological tools, Plant Sci. http://dx. doi.org/ 10.1016/j.plantsci.2014.04.005

Horst, R. K., 1983. Black spot. In: Compendium of Rose Diseases. The American Phytopathological Society, APS Press, St. Paul, Minnesota, pp.711.

Mangandi, J., and Peres, N. A. 2009. Black spot of rose, University of Florida IFAS Extension, Publication \#PP268. http://edis.ifas.ufl.edu/pp268.

Wenefrida, I., and Spencer, J. A. 1993. Marssonina rosae variants in Misssisippi and their virulence on selected cultivars. Plant dis., 77: 246248.

\section{How to cite this article:}

Sunita Chandel, Praneet Chauhan and Reetika Panwar. 2017. Occurrence of Black Spot of Rose, Marssonina rosae from Himachal Pradesh, India. Int.J.Curr.Microbiol.App.Sci. 6(8): 3058-3060. doi: https://doi.org/10.20546/ijcmas.2017.608.365 